\title{
EGFR NM_005228.3:C.2572C>A
}

National Cancer Institute

\section{Source}

National Cancer Institute. EGFR NM 005228.3:C.2572C>A. NCI Thesaurus. Code C98511.

A nucleotide substitution at position 2572 of the coding sequence of the EGFR gene where cytosine has been mutated to adenine. 